\title{
GENOTYPIC AND PHENOTYPIC CHARACTERIZATION OF Alcaligenes javaensis JG3 POTENTIAL AS AN EFFECTIVE BIODEGRADER
}

\author{
STALIS NORMA ETHICA ${ }^{1,2 *}$, OEDJIJONO ${ }^{3,4}$, ENDANG SEMIARTI ${ }^{2,3}$, JAKA WIDADA $^{2,5}$ \\ and TRI JOKO RAHARJO ${ }^{2,6,7}$ \\ ${ }^{1}$ Faculty of Nursing and Health Sciences, Universitas Muhammadiyah Semarang, Semarang 50273, Indonesia \\ ${ }^{2}$ Biotechnology Study Program, Graduate School, Universitas Gadjah Mada, Yogyakarta 55281, Indonesia \\ ${ }^{3}$ Faculty of Biology, Universitas Gadjah Mada, Yogyakarta 55281, Indonesia \\ ${ }^{4}$ Faculty of Biology, Universitas Jenderal Soedirman, Purwokerto 53122, Indonesia \\ ${ }^{5}$ Faculty of Agriculture, Universitas Gadjah Mada, Yogyakarta 55281, Indonesia \\ ${ }^{6}$ Faculty of Mathematics and Natural Science, Universitas Gadjah Mada, Yogyakarta 55281, Indonesia \\ 'LPPT Unit III Laboratory, Universitas Gadjah Mada, Yogyakarta 55281, Indonesia
}

Received 18 December 2015/Accepted 09 November 2017

\begin{abstract}
Utilization of glycerol by lipase producing bacteria offers great benefits for fat and oil waste degradation and waterwaste treatment. Nevertheless, there have been lack of reports about the availability of non-pathogenic, lipase producing bacteria, which could naturally degrade glycerol produced from the lipolysis process by lipase. This study reported a newly identified species of rhizobacteria, Alcaligenes javaensis JG3, which is not only able to produce high level of lipase, but also able to degrade glycerol molecules. Identification of strain JG3 was carried out using SEM (Scanning Electron Microscope), BD Phoenix 100 Automated Microbiology System and 16S rRNA gene analysis to determine its taxonomy status. The ability of the strain to metabolize glycerol was investigated both genotypically and phenotypically using degenerate PCR and a glycerol minimal medium. Identification test results showed that strain JG3 belongs to genus Alcaligenes, with the closest relationship with $A$. faecalis and $A$. aquatilis $(96 \%$ nucleotide similarity maximum). Degenerate PCR resulted in a 248-bp sequence showing 93\% similarity with glpK of Candidatus Sodalis pierantonius SOPE, a key gene involved in glycerol metabolism. In vitro glycerol utilization test result showed that Alcaligenes sp. JG3 was able to grow on glycerol aerobically, but not anaerobically. It is concluded that Alcaligenes sp. JG3 possesses genes coding for glycerol metabolism and this trait is phenotypically expressed, thus making the strain potential to be used as an effective fat and oil biodegrader.
\end{abstract}

Keywords: Alcaligenes, biodegradation, degenerate PCR, glpK, glycerol metabolism

\section{INTRODUCTION}

Strain JG3 is a soil rhizobacterium originated from root of Zea mays cultivated in an agricultural land in Purwokerto, Central Java Province, Indonesia. Previously regarded as Azospirillum species, the strain could grow in a mixture of bran and cassava medium containing fats for 8 weeks (Oedjijono et al. 2003; Ethica et al. 2013a, 2013b). Strain JG3 is an attractive research object because strain JG3 is capable of producing quite high level of lipase (Lestari et al. 2009, 2016). Enzyme

\footnotetext{
* Corresponding author: norma@unimus.ac.id
}

activity of crude lipase extract produced by strain JG3 was $25 \mathrm{U} / \mathrm{mL}$, which was considered higher than those previously reported about Bacillus subtilis $168 \mathrm{BCL} 1002(15 \mathrm{U} / \mathrm{mL})$ and other wildtype rhizobacterial strains isolated from soil, such as Pseudomonas spp., Bacillus sp., Staphylococcus aureus and Micrococcus lutens (10 to $17 \mathrm{U} / \mathrm{mL}$ ) (Lestari et al. 2009; Lesuisse et al. 1993; Charulatha et al. 2012). Nevertheless, the taxonomy status of strain JG3 is unclear because a polyphasic study has not been conducted.

Biological utilization of glycerol has been observed in lipase producing bacteria, such as Anaerovibrio glycerini sp. nov., Serratia marcescens and 
Pseudomonas aeruginosa (Schauder \& Schink 1989; Prasad \& Manjunath 2012). However, not all lipase producing bacteria can utilize glycerol released from the lipolysis process allowing effective degradation of fat and oil waste. For example, bacterial strain Burkholderia arboris SL1B1, which secretes lipase and assimilates fatty acids cannot utilize glycerol as a carbon source (Matsuoka et al. 2009). On the other hand, applications involving glycerol metabolism have been reported from species of genera Klebsiella, Citrobacter, Enterobacter, Clostridium, Lactobacillus, Bacillus, Propionibacterium and Anaerobiospirillum (Yazdani \& Gonzales 2007). Unfortunately, the potential uses of these organisms are limited due to issues including pathogenicity (Murarka et al. 2008).

Key enzymes in glycerol metabolism of bacteria are G3PDH (glycerol-3-phosphate dehydrogenase) and GK (glycerol kinase) coded by structural $g l p D$ and $g h k K$ genes (Pettigrew et al. 1988; Holmberg et al. 1990). Expression of two genes encoding glycerol-3-phosphate dehydrogenase and glycerol kinase, the $g / p D$ and $g h K$, was necessary and sufficient to enable growth of Corynebacterium glutamicum on glycerol as the sole carbon and energy source (Litsanov et al. 2012).

Williams et al. (1994) reported that a Gramnegative strain, Pseudomonas aeruginosa NM48, has ability to hydrolyse diacylglycerol using its extracellular lipases to form glycerol and fatty acids and also has ability to perform glycerol uptake. Results of the study by Williams et al. (1994) demonstrated that washed cells of strain P. aeraginosa NM48 prepared from cells grown on batch culture with glycerol as carbon source exhibited high glycerol uptake, glycerol kinase and glycerol-3-phosphate dehydrogenase activities.

The ability of strain JG3 to produce lipase enzyme is an indication that the strain could potentially be used in microbial degradation of fats and oils, which is important for the treatment of wastewater from restaurants and food industries (Matsuoka et al. 2009). Also, investigation of new strain which is nonpathogenic, facultative anaerobic and easy-togrow with adequate genetic information enabling genetic manipulation is important to lead toward effective microbial degradation. Therefore, this study was aimed to identify key genes involved in glycerol metabolism and to investigate the ability of strain JG3 in performing glycerol metabolism as an effective biodegrader.

\section{MATERIALS AND METHODS}

\section{Bacterial Strain}

Rhizobacterial strain JG3 used in this study was kindly provided by $\mathrm{Mr}$ Oedjijono (as generous gift) from Microbiology Laboratory, Faculty of Biology, Universitas Jenderal Soedirman, Indonesia.

\section{Subculture and Cultivation of Glycerol Degrading Bacterial Strain}

Strain JG3 previously received as culture on nutrient agar medium was immediately stored at $15^{\circ} \mathrm{C}$. Several plates and tubes containing instant $20 \mathrm{~g} / \mathrm{L}$ NA (Nutrient Agar), $15 \mathrm{~g} / \mathrm{L}$ TSA (Tryptic Soy Agar) with 5\% sheep blood, $20 \mathrm{~g} / \mathrm{L}$ MacConkey and $8 \mathrm{~g} / \mathrm{L} \mathrm{NB}$ (Nutrient Broth), were prepared. Strain JG3 was then purified using single-cell colony technique. Colonies having circular, regular and flat shapes with whiteyellowish color were selected and grown on both NA and NB media at $30{ }^{\circ} \mathrm{C}$ for 24 hours. Single colonies from the pure culture were also inoculated on TSA having 5\% sheep blood and MacConkey plates at similar temperature condition to identify the possibility of strain JG3 in exhibiting pathogenic characteristics, one of which is causing blood haemolysis. Pure cultures on NA were used for direct colony PCR (PCR using bacterial cells as template without prior DNA extraction).

\section{Phylogenetic Analysis}

A cladogram was created using neighbor-joining algorithm developed by Saitou and Nei (1987) based on the obtained sequence of $16 \mathrm{~S}$ rRNA gene of bacterium Jg3. Its homologs in other rhizobacteria retrieved from GenBank database were created using MEGA 6.0 software. The estimates calculations on evolutionary divergence among sequences were determined using maximum composite likelihood model (Tamura et al. 2004, 2013). All required alignments were carried out using ClustalW (Thompson et al. 2002). 


\section{Degenerate Primer Design}

Sequences of $g / p K s$ required to design degenerate primers were obtained from GenBank. Global alignments were performed using ClustalW (Thompson et al. 2002) and were used as input for Primaclade (Gadberry et al. 2005). A pair of primers having the least possibility of hairpin formation, selfcomplementarity and dimerization was selected.

\section{Gene Isolation}

Amplification by colony PCR using the designed primers aiming to amplify the $g / p K$ partial region (GKF and GKR) was performed in a $25 \mu \mathrm{L}$ reaction volume at annealing temperature of $50{ }^{\circ} \mathrm{C}$ with other PCR parameters set as previously described (Ethica et al. 2013b, 2017). The isolated DNA from this process was purified, followed by sequencing. The sequencing of all PCR products was conducted using BigDye ${ }^{\circledR}$ Terminator v3.1 sequencer system (Applied Biosystem, USA). The obtained sequences were ready for analysis.

\section{BLAST and Sequence Analysis}

The sequence of partial $g / p K$ and $16 \mathrm{rRNA}$ genes were deposited in GenBank to obtain accession number. Homology analyses were performed using BLASTn and BLASTx (Altschul et al. 1997). The alignments based on deduced amino acids were conducted using ClustalW (Thompson et al. 2002). The phylogenetic relationship of the obtained sequence with other sequences referred by BLAST from other organisms already deposited in GenBank was determined using MEGA 6.0 (Tamura et al. 2004, 2013).

\section{In vitro Glycerol Utilization Test}

A small-scale in vitro glycerol utilization test was performed to identify the ability of JG3 isolate in utilizing glycerol both in aerobic and anaerobic conditions. For starter, cultured bacterial cells (1 $\mu \mathrm{L}$ 24-hours) from NB medium was added into a reaction tubes containing $10 \mathrm{~mL}$ of autoclaved minimal medium loaded with $90 \mathrm{~g} / \mathrm{L}$ glycerol, $0.26 \mathrm{~g} / \mathrm{L} \mathrm{MgCl}_{2}, 0.01 \mathrm{~g} / \mathrm{L} \mathrm{NaMoO}_{4} \cdot 2 \mathrm{H}_{2} \mathrm{O}, 10.9$ $\mathrm{g} / \mathrm{L} \quad \mathrm{KH}_{2} \mathrm{PO}_{4}, 2.84 \mathrm{~g} / \mathrm{L}_{2} \quad \mathrm{~K}_{2} \mathrm{HPO}_{4}, 0.08 \mathrm{~g} / \mathrm{L}$ $\left(\mathrm{NH}_{4}\right)_{2} \mathrm{SO}_{4}, \quad 0.66 \mathrm{~g} / \mathrm{L} \quad \mathrm{NH}_{4} \mathrm{Cl}, 0.016 \mathrm{~g} / \mathrm{L}$
$\mathrm{MnCl}_{2} \cdot 4 \mathrm{H}_{2} \mathrm{O}, 0.02 \mathrm{~g} / \mathrm{L} \mathrm{CaCl} \cdot 2 \mathrm{H}_{2} \mathrm{O}, 0.018 \mathrm{~g} / \mathrm{L}$ $\mathrm{FeSO}_{4} \cdot 7 \mathrm{H}_{2} \mathrm{O}$ and $1 \mathrm{~g} /$ L yeast extract. Into $100 \mathrm{~mL}$ of the minimum medium, $1 \mu \mathrm{L}$ starter was introduced in two larger tubes under aseptic condition, incubated at $37{ }^{\circ} \mathrm{C}$ for 48 hours. One tube was put in an anaerobic jar (Anaerocult, Merck) which cap was loosely placed on the tube to allow gas exchange, but avoiding evaporation; the jar was placed on a shaker. The other tube was also put on a shaker with tightly placed cap. This experiment was carried out in triplicates. The fermentation was non-pH controlled and nonstirred, due to the low reaction volume. After 48 hours of fermentation, the $10-\mathrm{mL}$ fermentation sample was acidified to $\mathrm{pH}=2.0$ with $17 \%$ $\mathrm{H}_{3} \mathrm{PO}_{4}$. The $\mathrm{pH}$ was checked using $\mathrm{pH}$ indicator strips ( $\mathrm{pH} 2.0$ to 9.0, Merck). The acidified fermentation sample was centrifuged at 5,000 rpm (3,836 x g) for 20 minutes in a Beckman Avanti J-251 centrifuge at room temperature. After centrifugation, supernatants were collected and filtered through a 0.45 -m-pore-size filter (Milipore, Denmark). As much as $1 \mathrm{~mL}$ supernatant of fermentation sample was subjected to gas chromatography - mass spectroscopy (GC-MS) assay.

\section{GC-MS Assay of Glycerol Utilization}

Gas chromatography-mass spectroscopy (GC-MS) assays were performed to detect possible growth of strain JG3 in minimal glycerol broth under aerobic condition and to identify glycerol fermentation products which might be expressed by genes involved in its glycerol metabolism. Composition of two samples (aerobic and anaerobic isolates) was analyzed using GC spectrophotometer GD 2010 SHIMADZU equipped with MS detector, a Rastek RXi-5MS polysiloxilane column, and He (helium) as the carrier gas for the presence of any possible fermentation products. Each sample was prepared by adding $10 \mu \mathrm{L}$ of $6 \mathrm{~N} \mathrm{HCl}$ to a $900 \mu \mathrm{L}$ of cell-free sample (Kim 1991). Helium gas as the carrier gas was used. The temperatures of column oven, injector and detector were $40{ }^{\circ} \mathrm{C}, 310{ }^{\circ} \mathrm{C}$ and $250{ }^{\circ} \mathrm{C}$, respectively. The temperature gradient was as follows: $40{ }^{\circ} \mathrm{C}$ for 5 minutes, ramped at $10^{\circ} \mathrm{C}$ to $280{ }^{\circ} \mathrm{C}$ per minute, with 31 minutes hold time. The injection mode was split, column flow was $0.56 \mathrm{~mL} /$ minute and the total flow was $40 \mathrm{~mL} /$ minute. 


\section{Phenotypic Characterization}

Phenotypic characterization was conducted based on analysis of bacterial cell morphology, biochemical tests, tests of the ability of the strain to degrade glycerol substrate. Morphological tests were conducted to examine the colony morphology of strain JG3 on nutrient, MacConkey and TSA agar media including the shape, color, end, elevation and structure of the colonies. Observation on strain's cell morphology was conducted using Scanning Electron Microscope (SEM) with 7,500x magnification. For SEM observation, fresh bacterial cells were suspended in a phosphate-buffered salt solution. The cells were then fixed with $0.5 \%$ glutaraldehyde, washed several times and dehydrated in a series of ethanol concentrations. After the cells were sputter coated with goldpalladium, they were observed with an SEM (model JSM $6300 \mathrm{~F}$; JEOL, Japan) at $3 \mathrm{kV}$.

Gram-staining was performed based on previously reported method (Hucker 1921). For biochemical test, an automated system BD Phoenix 100 was utilized with protocols suggested by the manual of the instrument. Culture from solid medium was first suspended in Phoenix ${ }^{\mathrm{TM}}$ ID broth to adjust in $0.5-0.6 \mathrm{McF}$ arland turbidity using a Crystal Spec nephelometer. A drop of Phoenix AST indicator solution was added to each Phoenix ${ }^{\text {TM }}$ AST broth tube prior to inoculation with $25 \mu \mathrm{L}$ of the suspension in a final concentration of $5 \times 105 \mathrm{CFU} / \mathrm{mL})$. NMIC/ID-5 Phoenix ${ }^{\mathrm{TM}}$ panels were inoculated within 30 minutes of initial preparation. Panels were scanned and placed into the Phoenix ${ }^{\mathrm{TM}}$ instrument for incubation at $35^{\circ} \mathrm{C}$, followed by reading.

\section{Phylogenetic Characterization of Glycerol Degrading Bacterial Strains}

Genomic DNA for phylogenetic characterization was extracted and purified using PureLink ${ }^{\circledR}$ Quick Gel Extraction Kit following instructions of its manufacturer (Promega 2010). The 16S rRNA genes were amplified using PCR w i th primers of $27 \mathrm{f}$ ( $5^{\prime}$ AGAGTT'TGATCCTGGCCTCAG-3') and 1492r (5'-GGTTACCTTGTTACGACTT-3'). The 16S rRNA gene amplification was carried out using genomic DNA of the strain as template (Turner et al. 1999). PCR (Thermal Cycler Applied Biosystem) was performed to amplify the $16 \mathrm{~S}$
rRNA genes in a final volume of $25 \mu \mathrm{L}$, which consisted of genomic DNA (50 ng/ $\mu \mathrm{L}) 0.5 \mu \mathrm{L}$, 8f- $1492 \mathrm{r}$ primers $(10 \mu \mathrm{M}) 1 \mu \mathrm{L}$ each, 12.5 polymerase kit and $10 \mu \mathrm{L} \mathrm{dH_{2 }} \mathrm{O}$. Amplification was carried out at $95^{\circ} \mathrm{C}$ for 4 minutes; 30 cycles at $95{ }^{\circ} \mathrm{C}$ for 30 seconds, 30 cycles at $55^{\circ} \mathrm{C}$ for 30 seconds, 30 cycles at $72{ }^{\circ} \mathrm{C}$ for 2 minutes and the final extension at $72{ }^{\circ} \mathrm{C}$ for 7 minutes.

The sequences of the 16S rRNA genes from each isolate were used as query to determine the genes and species of its closest proteobacterial relative using BLASTN (Altschul et al. 1990). Subsequently, sequences were aligned using CLUSTAL X program developed by Thompson et al. (1994). Phylogenetic trees were inferred by the neighbor-joining method (Saitou \& Nei, 1987) with the phylogenetic analysis package MEGA 6.0, which included the use of tools to plot the tree topologies. To provide confidence estimates for branch support, a bootstrap analysis was performed in 1,000 replications (Felsenstein 1985). Reference sequences of $16 \mathrm{~S}$ rRNA genes were obtained from Genbank, which were included in the phylogenetic analysis (Chaerun et al.2012; Sya'di et al. 2017).

\section{RESULTS AND DISCUSSION}

\section{Taxonomy Status of Strain Jg3}

Taxonomy status of strain JG3 was determined using polyphasic approach involving morphological, biochemical and molecular identifications. Growth of single colonies of strain JG3 was first obtained from colony purification using NA medium showing different results on three plates containing NA, TSA with $5 \%$ sheep blood and MacConkey agar. Morphology of colonies grown on the three media is displayed in Figure 1.

Strain JG3 could grow on NA, a common medium for a wide variety of bacteria, displaying round, irregular, smooth, flat shapes with yellowish color (Fig. 1). Strain JG3 could also grow on TSA media containing blood without causing haemolysis typically exposed by pathogenic bacteria attacking blood. On TSA medium, strain JG3 showed punctiform, dry, irregular shapes with greyish color. After the Gram-staining process, strain JG3 showed characteristics as a Gram-negative bacterium. The 


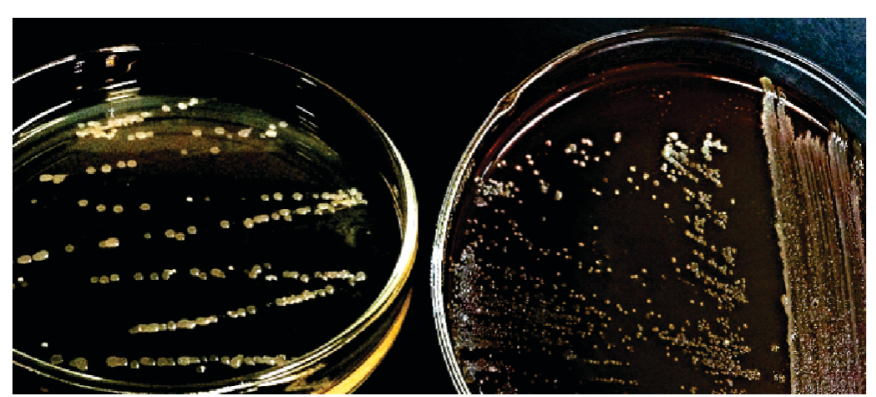

A

B

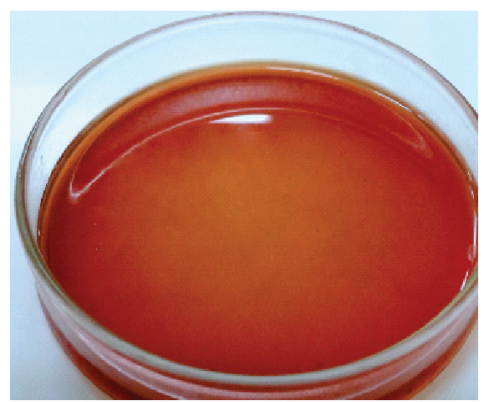

C

Figure 1 Observed growth of bacterial strain JG3 on various agar media after 24 -hour incubation at $30{ }^{\circ} \mathrm{C}$ : A. Growth on nutrient agar; B. Growth on TSA agar plate containing 5\% blood; C. No growth was observed on MacConkey agar plate

ability of strain JG3 to grow on various media without the need of strict temperature condition or specific treatment showed that the rhizobacterium was easy to grow. However, it did not show growth on MacConkey agar plate).

MacConkey medium is commonly used to cultivate Gram-negative, enteric, pathogenic bacteria (Allen 2005). Inability of the bacteria to grow on MacConkey agar medium is also a typical sign that the bacteria could not ferment lactose (Allen 2005). Results of this study showed that strain JG3 was able to grow both on complex and blood containing media without causing blood haemolyses, indicating that the strain could be categorized as an opportunistic organism, but not significantly pathogenic.

Cellular morphology of strain JG3 was further examined using Scanning Electron Microscopy (SEM) showing the appearance of strain JG3 cells as rods or coccobacilli having width of $0.7-1.0$ $\mu \mathrm{m}$ (Fig. 2).

According to SEM result, typical cells of strain JG3 were slightly varied in size, but basically were rod-shaped occurring as single, in pairs or short chains. In terms of morphological characteristics, the punctiform-shaped colonies of strain JG3 on TSA medium matched the characteristics of Gram-negative rhizobacteria, Alcaligenes, belonging to sub-phylum Betaproteobacteria. Cells of strain JG3 did not show any curved or vibrioid shapes, yet only straight rods or coccobacilli having sizes of $0.7-1.0 \times 0.5-2.6 \mu \mathrm{m}$, which were smaller than most Bacillus members. The Bergey's manual states that Alcaligenes are members of the class Betaproteobacteria.

Biochemical assay on strain JG3 was carried out using BD (Beckton Dickinson) Phoenix 100 Automated Microbiology System.

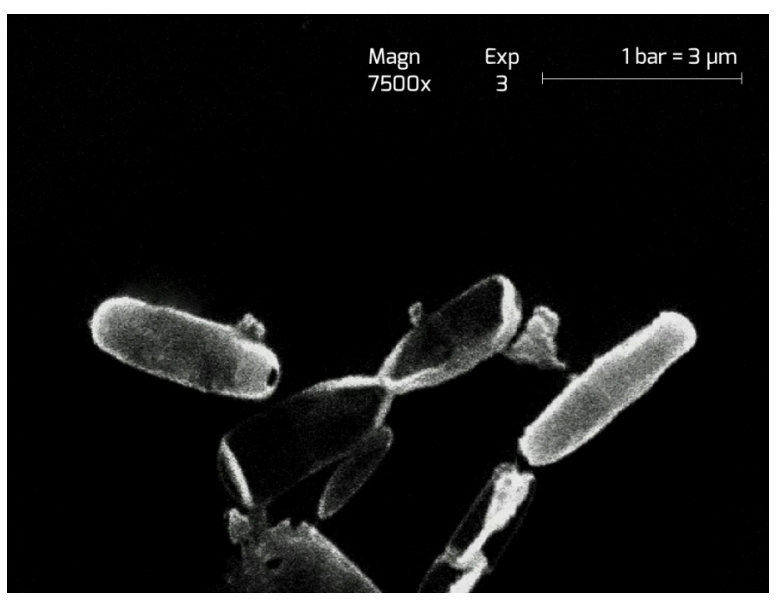

Figure 2 Cells of bacterial strain JG3 observed under Scanning Electron Microscope (SEM; JEOL, 5310-LV; 20kV) 


\begin{tabular}{|c|c|c|c|c|c|c|c|c|}
\hline Accession \# & \multicolumn{2}{|c|}{$1603 \mathrm{mk}$} & & & \multicolumn{2}{|l|}{ Test Start } & \multicolumn{2}{|c|}{ 02/25/14 09:16 } \\
\hline Isolate \# & \multicolumn{2}{|c|}{1} & & & \multirow{2}{*}{\multicolumn{2}{|c|}{ Test End }} & \multicolumn{2}{|c|}{$02 / 25 / 1421: 28$} \\
\hline Sequence \# & \multirow{2}{*}{\multicolumn{2}{|c|}{$\begin{array}{l}420071267240 \\
\text { NID }\end{array}$}} & & & & Instr \# / Station & \multicolumn{2}{|c|}{$1 / \mathrm{D} 03$} \\
\hline Panel Type & & & & & \multirow{2}{*}{\multicolumn{2}{|c|}{ Finalized }} & \multirow{2}{*}{\multicolumn{2}{|c|}{ No }} \\
\hline Status & \multicolumn{3}{|c|}{ COMPLETE } & & & & & \\
\hline Final ID & \multicolumn{3}{|c|}{ Alcaligenes faccalis } & & \multicolumn{2}{|c|}{ Inoculum Density } & \multicolumn{2}{|l|}{0.5} \\
\hline \multirow{2}{*}{\multicolumn{2}{|c|}{$\begin{array}{l}\text { Instrument ID(s) } \\
\text { Alc. faccalis }\end{array}$}} & \multicolumn{2}{|c|}{ Confidence Value } & & & & & \\
\hline & & & $99 \%$ & & & & & \\
\hline & Instr & Expected & & Instr & Expected & & Instr & Expected \\
\hline Biochemical & $\underline{\text { Result }}$ & $\underline{\text { Result }}$ & Biochemical & $\underline{\text { Result }}$ & $\underline{\text { Result }}$ & Biochemical & $\underline{\text { Result }}$ & \\
\hline A_ARARR & - & - & A_GLPRB & - & - & A_GLYB & - & $\mathrm{v}$ \\
\hline A_GUGAH & - & - & A_LARGH & - & $\mathrm{v}$ & A_LGTA & - & - \\
\hline A_LLEUH & - & $\mathrm{v}$ & A_LPHET & - & - & A_LPROB & - & - \\
\hline A_LPYR & - & - & A_LTRY & - & - & A_LYALD & - & - \\
\hline C_ACT & + & $\mathrm{v}$ & C_ADO & + & $\mathrm{v}$ & $\mathrm{C}_{-} \mathrm{CIT}$ & + & + \\
\hline C_CLST & + & $\mathrm{v}$ & C_DMNT & + & + & $\mathrm{C}_{-} \mathrm{KGA}$ & + & + \\
\hline C_MLO & + & + & C_PXB & - & $\mathrm{v}$ & C_TIG & + & $\mathrm{v}$ \\
\hline M_NAG & - & & N_LGGH & + & $v$ & N_LPROT & + & $\mathrm{v}$ \\
\hline P_BDGLU & + & $v$ & P_BPHO & + & $v$ & $R_{-}$BALL & - & - \\
\hline R_BGEN & - & - & R_DEX & - & - & R_DFRU & - & - \\
\hline R_DGAL & - & - & R_DGUA & - & - & R_DMLB & - & - \\
\hline R_DSBT & & - & R_DSUC & - & - & R_GRA & - & - \\
\hline R_LARA & & - & R_LRHA & - & - & R_MBGU & - & - \\
\hline R_MTU & - & - & R_NGA & - & - & R_NGU & - & - \\
\hline S_ORN & - & - & S_URE & - & - & T_ESC & & - \\
\hline
\end{tabular}

Figure 3 BD Phoenix 100 screening report on strain JG3

Forty-four biochemical characteristics of strain JG3 were shown as the output of BD Phoenix 100 Automated Microbiology System (Fig. 3). Based on the BD Phoenix screening readout, strain JG3 was detected as species Alcaligenes faecalis rhizobacterium with $99 \%$ confidence.

Genotypic identification of strain JG3 relied on the analysis of $16 \mathrm{~S}$ rRNA gene using universal or species-strain specific primers. Amplification of partial 16S rRNA gene from strain JG3 using genomic DNA as template (seen as a band at $\sim 4,000 \mathrm{bp}$ ) resulted in single DNA band on TAE-electrophoresis gel with a size of $\sim 1,500 \mathrm{bp}$ (Fig. 4). The DNA band was excised from gel, purified and sequenced resulting in 1,511-bp nucleotide sequence, which was then deposited in GenBank under accession number of Ab914514.

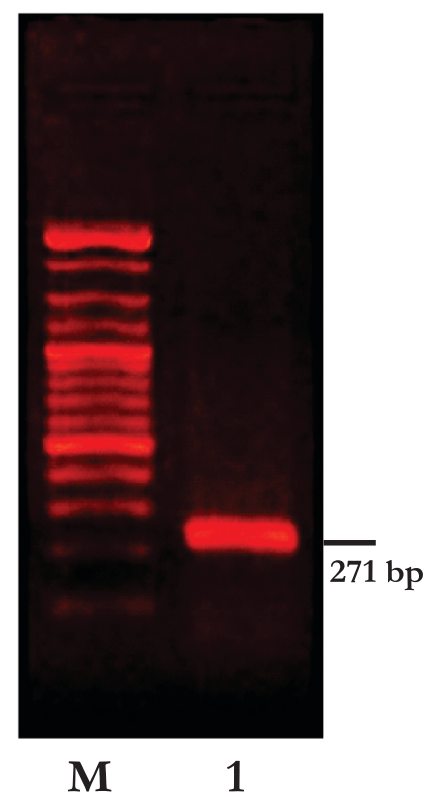

Figure 4 Gel electrophoresis analysis of PCR products using GKF and GKR primers: $\mathrm{M}$ = Marker, Lane $1=$ Amplified DNA fragment using GKF1 and GKR primers 


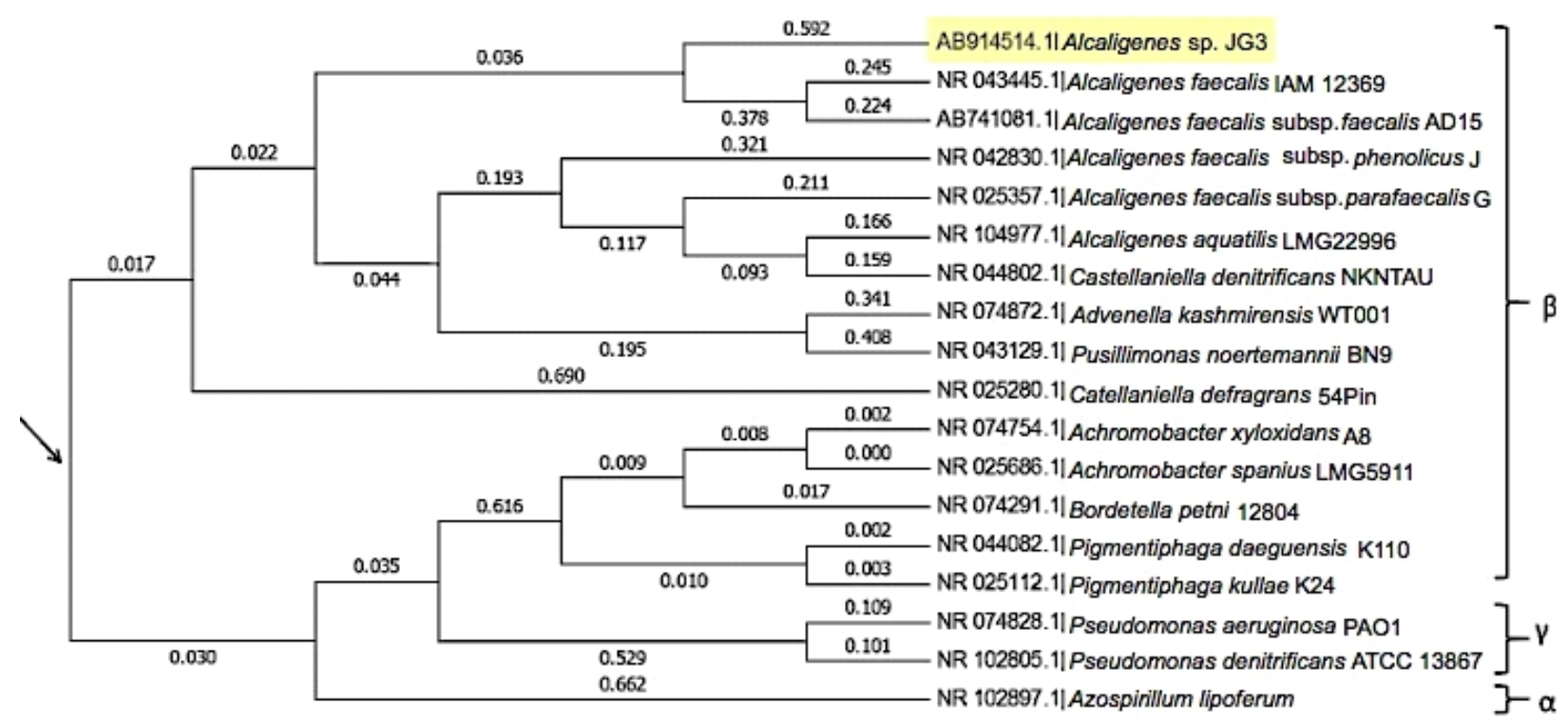

Figure 5 A cladogram showing position of strain JG3 strain based on 16S rRNA gene sequence relative to other bacteria (Note: This cladogram was created using MEGA 6.0, a program developed by Tamura et al. 2013)

Results of identification tests revealed that strain JG3 belongs to Alcaligenes genus, namely Alcaligenes sp. JG3. Although the results of morphological and biochemical tests showed that the strain resembled Alcaligenes faecalis having coccobacillus cell shapes and having BD Phoenix confidence of $99 \%$, the phylogenetical features of the strain based on 16S rRNA exposed only had $96 \%$ similarity to the closest species in phylogenetic tree (Fig. 5).

The similarity level was below the suitable similarity cut-off for the identification of new taxa at genus and species levels based on 16S rRNA gene, which are $97 \%$ and $99 \%$, respectively (Drancourt et al.2000).

Based on phylogenetic analysis and results of morphological and biochemical tests, in accordance with Bergey's Manual of Determinative Bacteriology (Garrity et al. 2005), a novel species of the genus Alcaligenes isolated from root of Zea mays cultivated in a land of Central Java Province, Indonesia, Alcaligenes javaensis strain JG3 is proposed.

\section{Detection of glpK}

Degenerate PCR colony using GKF (5'ATCGGCATCACCAACCAGC-3') and GKR (5'- GGYCACRTCCTCGCCATC -3') primers designed using Primaclade resulted in a single band on gel electrophoresis corresponding to DNA size of around 271 bp (Fig. 5). After sequencing, it was obtained as 248-bp nucleotide sequence deposited in GenBank database under accession number of AB894421. Result from BLASTn search indicated that the sequence shared $93 \%$ similarity with $g / p K$ of Candidatus Sodalis pierantonius SOPE ATCC 15264, suggesting that it is likely part of gene encoding glycerol kinase. This result was in line with the previous study revealing the presence of $g / p D$ in strain JG3, another key gene responsible for glycerol utilization (Ethica et al. 2013a) revealing that genotypically strain JG3 has ability to metabolize glycerol.

\section{Glycerol Degradation by Strain Jg3}

Results of the in vitro test showed that Alcaligenes sp. JG3 could grow on minimal medium containing glycerol as carbon source aerobically, but not anaerobically. After 48 hours, turbidity of medium in aerobic sample reached $\mathrm{OD}_{600}=1$ as sign of bacterial growth, which was later confirmed by results of GC assays. The obtained GC chromatogram (Fig. 6) of both aerobic and anaerobic samples were aligned showing shifted retention time (tR) by 3.3 minutes between two single peaks of both samples, which were identified as glycerol by mass spectra showing significance identity (SI) level of 95 and $96 \%$, respectively, with glycerol compound based on mass spectral matching with reference library. There was no significant substance other than glycerol detected by GC on both aerobic in anaerobic samples. The size of 


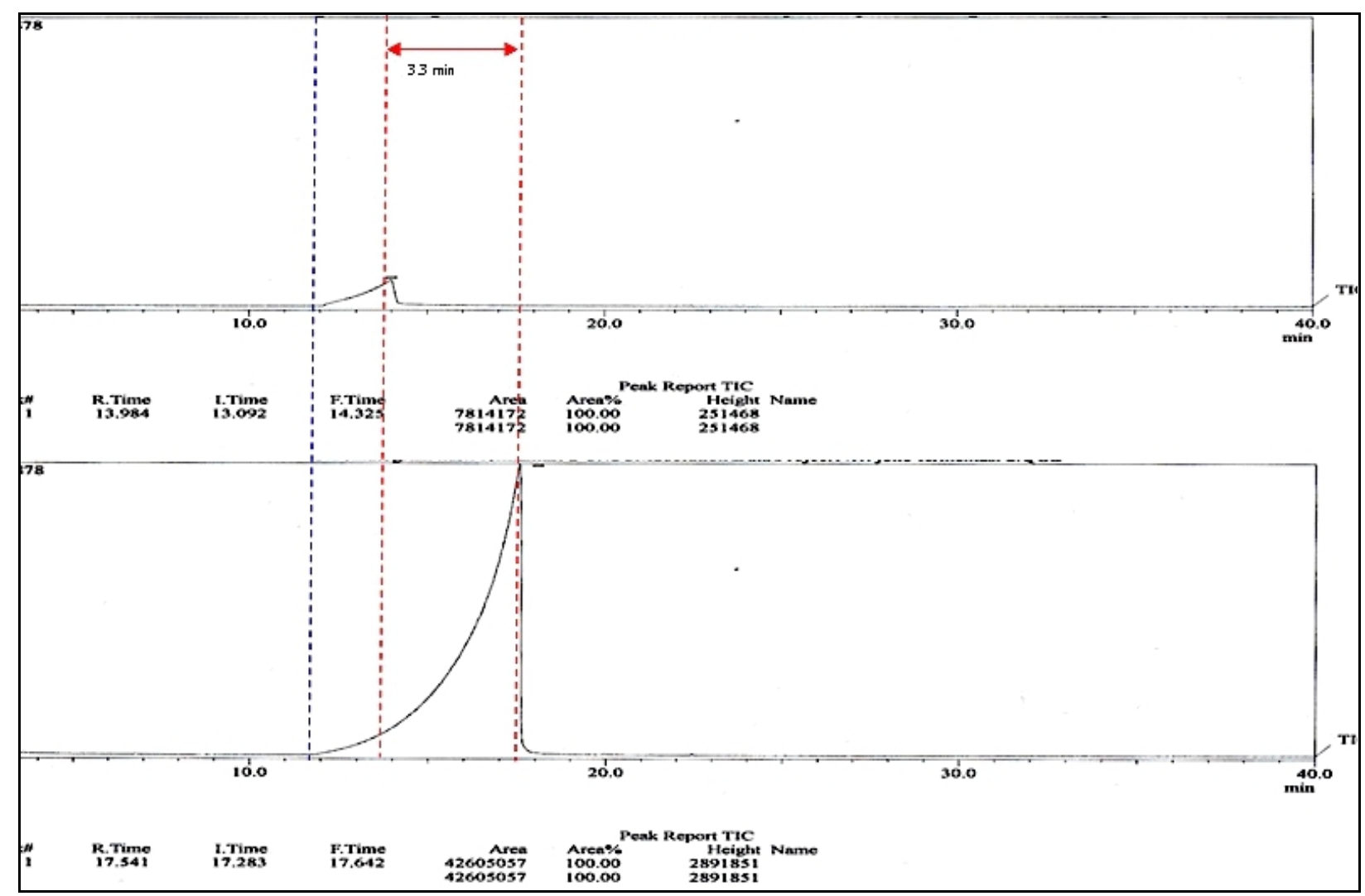

Figure 6 Chromatogram of liquid containing glycerol minimal medium and bacterial strain under aerobic (top) and anaerobic (below) conditions for 48 hours

glycerol peak area of anaerobic sample was larger than that of aerobic sample indicating that the concentration of glycerol in anaerobic sample was higher than that in aerobic sample. Since there was no growth in anaerobic sample, it was assumed that glycerol quantity in anaerobic samples represented the initial glycerol quantity of the samples. Thus, the lower glycerol concentration in aerobic sample after 48 hours incubation was a sign that glycerol in the medium was aerobically utilized by strain Jg3.

Identification on strain JG3 using polyphasic approach consisting of phenotypic and genotypic tests has been conducted in this study. By evaluating morphological, biochemical and phylogenetical features of strain JG3 based on information from Bergey's manual, the rhizobacterium was classified as genus Alcaligenes, namely Alcaligenes sp. JG3. As stated by Drancourt et al. (2005), 99\% similarity is a suitable cutoff for identification at species level and $97 \%$ similarity is suitable cutoff for identification at genus level to determine new species based on 16S rRNA gene. This means that strain JG3 has high level of novelty, both in genus and species levels.
Results of glycerol utilization tests for strain JG3 showed that the strain, which was previously known as lipase producer, also has an active aerobic glycerol metabolism. As stated in Bergey's manual, $A$. faecalis and its subspecies (A. faecalis subsp. faecalis and $A$. faecalis subsp. parafaecalis) usually have no ability to grow on glycerol. $A$. latus was found to have the ability to utilize glycerol, but no associated data was found for the rest members of genus Alcaligenes (Garrity et al. 2005). Therefore, strain JG3 has uniqueness, distinguishing the strain from other members of genus Alcaligenes in terms of glycerol utilization.

Glycerol utilization property of strain JG3 also shows the ability of the strain to effectively degrade fat. It is possible for strain JG3 to degrade fat using lipase produced by itself and subsequently metabolize glycerol resulted from this degradation process. The ability of strain JG3 to produce lipase enzyme along with the ability to utilize glycerol aerobically is a strong indication that the strain could potentially be used as an effective degrader of oils and fats. Such ability is essential for application in wastewater treatment including in grease-traps installed for the 
treatment of wastewater from restaurants and food industries as initially developed by Matsuoka et al. (2009).

\section{CONCLUSIONS}

A new taxa of genus Alcaligenes identified in this study, Alcaligenes sp. JG3, possesses a gene involved in glycerol metabolism and has active glycerol metabolism shown by its ability to grow on a minimal glycerol medium. Strain JG3 also has ability to produce lipase enzyme indicating that strain JG3 could potentially be used as effective microbial degraders of fats and oils for application in wastewater treatment.

\section{ACKNOWLEDGEMENTS}

The manuscript was dramatically improved after receiving technical support from Clinical Program on Articles Writing in International Journal, Directorate of Intellectual Property Management, Ministry of Research, Technology and Higher Education (Kemenristek Dikti) of the Republic of Indonesia. The authors also acknowledge and thank Overseas Seminar Assistance Program, Directorate General of Research and Development Reinforcement of Kemenristek Dikti, for the support in publishing this paper.

Deep gratitude is due to Mr Tri Joko Raharjo from Laboratorium Penelitian Pusat Terpadu (LPPT), Universitas Gadjah Mada, Yogyakarta, Indonesia, for financial support and supervision to carry out this study. Great gratitude is also extended to Mr Oedjijono from Microbiology Laboratory, Faculty of Biology, Universitas Jenderal Soedirman, Indonesia, for providing living materials used in this study.

\section{REFERENCES}

Allen ME. 2005. MacConkey agar plates protocol. Washington (US): American Society for Microbiology. p. 1-4.

Altschul SF, Madden TL, Schäffer AA, Zhang J, Zhang Z, Miller W, Lipman DJ. 1997. Gapped BLAST and PSI-BLAST: A new generation of protein database search programs. Nucleic Acids Res. 25:3389-402.
Chaerun SK, Hasni S, Sanwani E, Moeis MR. 2012. Mercury $(\mathrm{Hg})$-resistant bacteria in $\mathrm{Hg}$-polluted gold mine sites of Bandung West Java Province. Indonesia Microbiol 6:57-68.

Charulatha R, Prabhakar S, Sivamani P, Kandeepan C, Tiagarajan V. 2012. Characterization of clinical application of extracellular lipase by microorganisms from soil. Int J Curr Sci 3:61-6.

Drancourt M, Bollet C, Carlioz A, Martelin R, Gayral JP, Raoult D. 2000. 16S ribosomal DNA sequence analysis of a large collection of environmental and clinical unidentifiable bacterial isolates. J Clin Microbiol 38:3623-30.

Ethica SN, Hammi MK, Lestari P, Semiarti E, Widada J, Raharjo TJ. 2013a. Amplification of Azospirillum sp. JG3 glpD gene fragment using degenerate primers generated by web-based tools. J Microbiol Biotech Food Sci 3:231-4.

Ethica SN, Nataningtyas DR, Lestari P, Istini I, Semiarti E, Widada J, Raharjo TJ. 2013b. Comparative evaluation of conventional versus rapid methods for amplifiable genomic DNA isolation of cultured Azospirillum sp. JG3. Indo J Chem 13:248-53.

Ethica SN, Semiarti E, Widada J, Oedjijono, Raharjo TJ. 2017. Characterization of moaC and a nontarget gene fragments of food-borne pathogen Alcaligenes sp. JG3 using degenerate colony and arbitrary PCRs. J Food Saf 37:e12345. Available from: https://doi.org/10.1111/jfs.12345.

Felsenstein J. 1985. Phylogenies and the comparative method. Am Nat 125(1):1-15.

Gadberry MD, Malcomber ST, Doust AN, Kellogg EA. 2005. Primaclade - a flexible tool to find conserved PCR primers across multiple species. Bioinformatics 21:1263-4.

Garrity GM, Bell JA, Lilburn T. 2005. Class I. Alphaproteobacteria class. nov. In: Brenner DJ, Krieg NR, Staley JT, editors. Bergey's Manual ${ }^{\circledR}$ of Systematic Bacteriology. Boston (US): Springer. 574 p.

Holmberg C, Beijer L, Rutberg B, Rutberg L. 1990. Glycerol catabolism in Bacillus subtilis: nucleotide sequence of the genes encoding glycerol kinase $(g h K)$ and glycerol-3-phosphate dehydrogenase $(g / p D)$. J General Microbiol 136:2367-75.

Hucker GJ. 1921. A new modification and application of the Gram stain. J Bacteriol 6:395-7.

Kim YJ. 1991. Modeling and application of aqueous 2phase system in a-b-e fermentation process. Master Thesis. Maryland (US): Advisor Weigand WA, University of Maryland.

Lestari P, Handayani SN, Oedjijono. 2009. Biochemical properties of crude extracellular lipase from Azospirillum sp.JG3. Molekul 4:73-82.

Lestari P, Raharjo TJ, Matsjeh S, Haryadi W. 2016. Partial purification and biochemical characterization of 
extracellular lipase from Azospirillum sp. JG3 bacteria. AIP Conference Proceedings 1755(1). p. 080003.

Lesuisse E, Schanck K, Colson C. 1993. Purification and preliminary characterization of the extracellular lipase of Bacillus subtilis 168, an extremely basic $\mathrm{pH}$ tolerant enzyme. Eur J Biochem 216:155-60.

Litsanov B, Brocker M, Bott M. 2012. Glycerol as a substrate for aerobic succinate production in minimal medium with Corynebacterium glutamicum. Microbial Biotechnol 6:189-95.

Matsuoka H, Miura A, Hori K. 2009. Symbiotic effects of a lipase-secreting bacterium, Burkholderia arboris SL1B1, and a glycerol-assimilating yeast, Candida cylindracea SL1B2, on triacylglycerol degradation. J Biosci Bioeng 107:401-8.

Murarka A, Dharmadi Y, Yazdani SS, Gonzalez R. 2008. Fermentative utilization of glycerol by Escherichia coli and its implications for the production of fuels and chemicals. App Environ Microbiol 74:1124-35.

Oedjijono, Ryandini D, Permiarti. 2003. Formulasi biofertilizer dari kultur campuran bakteri pemfiksasi nitrogen dan pelarut fosfat pada medium onggok dan dedak [Research report, unpublished]. Retrieved from Fakultas Biologi Universitas Jenderal Soedirman.

Pettigrew DW, Ma DP, Conrad CA, Johnson JR. 1988. Escherichia coli glycerol kinase, Cloning and sequencing of the $g l p K$ gene and the primary structure of the enzyme. J Biol Chem 263:135-9.

Prasad MP, Manjunath K. 2012. Effect of media and process parameters in the enhancement of extracellular lipase production by bacterial isolates from industrial effluents. Int J Microbiol Res 4:308-11.

Promega. 2010. Wizard® Genomic DNA purification kit, technical manual (Tm050), 3.G. Section, Isolating genomic DNA from gram-positive and gramnegative bacteria revised December. Madison (US): Promega Corporation.

Saitou N, Nei M. 1987. The neighbor-joining method: A new method for reconstructing phylogenetic trees. Mol Biol Evol 4:406-25.

Schauder R, Schink B. 1989. Anaerovibrio glycerini sp. nov., an anaerobic bacterium fermenting glycerol to propionate, cell matter and hydrogen. Arch Microbiol 152:473-8.

Sya'di YK, Wahyuni ET, Rahayu ES, Cahyanto MN. 2017. Cellulose produced by Gluconacetobacter xylinus BTCC B796. IJST 5(6):98-103.

Tamura K, Nei M, Kumar S. 2004. Prospects for inferring very large phylogenies by using the neighbor-joining method. PNAS 101:11030-5.

Tamura K, Stecher G, Peterson D, Filipski A, Kumar S. 2013. MEGA 6: Molecular evolutionary genetics analysis version 6.0. Mol Biol Evol 30:2725-9.

Thompson JD, Gibson T, Higgins DG. 2002. Multiple sequence alignment using ClustalW and ClustalX. Curr Protocols Bioinformatics:2-3.

Turner S, Pryer KM, Miao VP, Palmer JD. 1999. Investigating deep phylogenetic relationships among cyanobacteria and plastids by small subunit rRNA sequence analysis. J Euk Microbiol 46:32738.

William SG, Greenwood JA, Jones CW. 1994. The effect of nutrient limitation on glycerol uptake and metabolism in continuous cultures of Pseudomonas aeruginosa. Microbiology 140(11):2961-9.

Yazdani SS, Gonzalez R. 2007. Anaerobic fermentation of glycerol: a path to economic viability for the biofuels industry. Curr Opinion Biotechnol 18: 213-9. 